\title{
The Essential Role of Dance in the Fight Against the COVID-19 Outbreak
}

\section{舞蹈在抗击疫情中的必要角色}

\author{
Wei Zhang \\ Sichuan University of Media and Communications, China
}

\begin{abstract}
Since the outbreak of 2019 novel coronavirus (COVID-19) across China in early 2020, leaders of the Communist Party of China (CPC) and the state have given earnest consideration to the science-based epidemic prevention and control. With numerous health care professionals bravely saving lives on the frontline and countless ordinary people self-quarantining at home on the advice of experts, China is going all out to contain the COVID-19 spread. At this challenging time, a large number of dancers have taken action to boost people's morale through dance videos and ease public stress by offering free online dance lessons as workouts. Dance not only can help those stuck in home isolation and those infected with mild symptoms, it can relieve and release negative emotions and stress, but by keeping fit one can strengthen ones' immune system against the virus. Dance, with its unique aesthetic appreciation and artistic value, plays a significant role in society and humankind amid the epidemic crisis.
\end{abstract}

Keywords: Dance, COVID-19 crisis, epidemic, China

\section{摘要}

2020 年初，新型冠状病毒曼延全国，在这段抗击疫情的特殊时期，既有党和国家领导人 的高度重视和科学部署，又有不顾自身安危的医护工作者奋斗在抗疫的一线，全国人民 上下齐心听从专家建议，采取居家隔离来对抗疫情的扩散。在这段特殊的时期，众多的 舞者在行动，他们通过舞蹈视频来鼓舞士气，通过舞蹈公益课的形式来舒缓大众压力， 达到锻炼身体的目的。舞蹈不仅可以让居家隔离的大众和轻度新型冠状病毒患者缓解情 绪、放松压力，还可以达到强生健体、增强免疫能力来对抗病毒。舞蹈在这场突入的疫 情中以其独有的审美方式和艺术价值发挥着其对于社会、对于人类的重要作用。

关键词 : 舞蹈，COVID-19危机，流行性疾病，中国

As the COVID-19 (coronavirus) outbreak raged across the country in early 2020, China was confronted with a battle against the epidemic. The Chinese government stressed their unremitting efforts in epidemic prevention and control with scientific deployments, rigorous measures and sophisticated coordination among various departments. These been proven to be significantly effective due to the medical staff within the national health system working tenaciously together with all Chinese people to battle the coronavirus epidemic. Since February 6, 2020, patients from different communities who have displayed evens light symptoms have been successively earmarked for medical intervention and transferred to the cabin hospitals. These hospitals have been also 
praised as "cabins of life", where medical teams from all over the country are gathered to support those at the epicenter of the epidemic, Wuhan. Generally, these patients aged from 18 to 65 years old, are self-reliant without severe cardiopulmonary, respiratory, cerebral and renal-related basic diseases. The health workers have raced against the virus with the patients at these emergency hospitals. By 7:00 a.m. on February 13, 2020, seven temporary makeshift hospitals were operating, with a total of 4313 patients receiving treatment. Good news kept coming that hundreds of infected cases had been discharged making a full recovery supported by thorough medical care within a few days. These patients also participated in dance-oriented activities organized by the medical workers, lightening the mood of the hospitals. Some of them posted dance videos to social media via phones, drawing much attention and receiving praise from people at home and abroad. CCTV news broadcasts also reported that patients and medical staff could adjust their mood, lower anxiety and enhance physical fitness through dancing, which conveyed hope for those going through the epidemic. Dance plays an important role in society and for human beings with its unique aesthetic appreciation and artistic value.

Dance is one of the many art forms that has emerged with the evolution of human beings. In primitive society, it served as a sign language to assist verbal communication. In primitive tribes, dance was an integral part of sacrificial rituals. In the Han Dynasty, dance became a rigid social etiquette for official banquets. With the emergence of dance, its development reached a brilliant peak, embodying a major national fusion during the Tang Dynasty. Today, dance has become an indispensable part of spiritual civilization. Thus, it can be clearly seen that dance has played a major role throughout the development of human history of. The Great Preface to the Book of Poetry describes dancing as a human instinct, "when emotions overflow, we are eager to express in words; when words fail, we spontaneously sigh; when sighing seems not enough, we tend to sing; when singing is not enough, we cannot help moving our body to dance." The famous Chinese scholar Yiduo Wen also writes in his About Dance, "Dance is the most direct, essential, passionate, sharp, pure and thorough way of expression for life."

\section{Dance as a Morale Booster in Fighting the Epidemic}

\section{Active response of dancers at universities}

Since the outbreak of the epidemic, many art colleges in China have taken active action to create several dance pieces to help in the fight against the epidemic using the art of dance and body language, in an effort to cheer up the people of Wuhan and the whole country. Sichuan University of Media and Communications where I work also joined in this. Touched by the CCTV news report on February 3, 2020, that additional medical staff from across the country had rushed to the epicenter of the outbreak to support aid efforts, I was inspired to create a dance piece associated with the battle against coronavirus. It was during the first stage of national self-isolation when the COVID-19 outbreak swept the country that medical workers from all over the country rushed to fight on the medical frontline. Facing the relentless epidemic, everyone wants to do something meaningful. Despite concerns about the increasing infected 
cases reported in the news, we always have a strong faith that Chinese people will be brave enough to defeat the coronavirus outbreak. On February 4, we began to mobilize teachers and students living around the country to build creative teams through We Chat groups, in which the theme of the dance work was explained and choreographic tasks were assigned. We also called on students to record dance videos on their mobile phones at home and send them back to us for post-editing to complete the compositions. Everyone involved cooperated with each other actively so that we finished the dance piece "Stay strong, Wuhan!" in 2 days (February 6) whilst being mindful of our own safety. Released through the official Weibo, TikTok, and Wechat of Sichuan University of Media and Communications, this dance piece has been forwarded by many media outlets such as China Education Television, Beijing Campus Life, Toutiao Campus, China Dance Website, Sichuan Education Release, Sina Viewpoint Platform, Tencent News, Headline Today, The Cover, Sichuan Radio and Television News Live. This dance piece was viewed more than 1 million times and nearly 3 million times on TikTok within a few days. The faculty and university students with dance majors hope to make good use of the videos as a way to boost the morale of the whole country to fight against the epidemic through art as a unique way of expression.

\section{Dance artists in action}

Dance artists from all over the country also stepped forward. According to the news from its official WeChat on February 4, 2002, the China Literary and Art Volunteers' Association (CLAVA) initiated online activity for this voluntary art service-Healthy and Sustainable Life with Culture and Arts-in an active response to General Secretary Xi Jinping's important instructions on epidemic prevention and control together with the deployment of the Publicity Department of the Communist Party of China to promote civilization in the new era, advocating innovative implement of the "Chinese Dream with Culture into Households". On the list of the first batch of online training courses for the art volunteer service, we can find such names as: Doudou Huang, the famous dancer, vice chairman of the China Dancers Association (CDA) and vice chairman of China Literary and Art Volunteers' Association (CLAVA); the Uygur dance artist Gulimina; the dance couple of Ming Zeng and Fang Liu; the dancer Shuai Zhao; and the young dancers Xiang Li, Chanchan Gou and Shuo Yin. They have offered free online dance classes to those who are self-isolating at home nationwide, guiding them in learning Chinese classical dance, Chinese folk dance and other forms of dance to ease their minds and keep fit. In addition, under the guidance of the Sichuan Dancers Association and the Chengdu Dancers Association at "Dancing Against Coronavirus; We are Together", several popular dancers in Sichuan and across the country were invited to give free online dance classes in the form of teaching dance sequences, dance analysis and appreciation, and dance recommendations. They not only demonstrated dance movement in person, but also put them it into segments so that those enjoying dancing all over the country could keep working out while gaining some dance knowledge through the Internet. 


\section{Dance for a Better Clinical Atmosphere}

\section{Patients dancing}

A video clip went viral on February 6, 2020, showing Mrs. He with a medical protective mask wearing yellow cotton pants and warm cotton shoes dancing. Interviewed by a journalist for The Paper on February 9, 2020, she said that she had been diagnosed with the new coronavirus-related pneumonia with mild symptoms and sent to the cabin hospital that had been converted from the Wuhan International Conference and Exhibition Centre on February 5, 2020. Since she was able to take care of herself, she recorded a video in which she moved confidently and smoothly in front of her sickbed to Xiao Liu's song, The Last Outpouring, inspired by another patient who had danced on the ward. After she posted it to social media, she hoped her positive attitude towards the virus could comfort her family members. Another patient in the hospital nicknamed "A Bu" recalled that he noticed everyone was excited when dancing together. At first when the music was put on in the gloomy ward, they did not pay much attention to it. Then, more patients got up and gradually started dancing. Although some could not keep up with the rhythm, most of them were smiling by the end. The ward was filled with laughter and enthusiasm after dancing together in that moment. They encouraged each other through eye contact with joy at the end of the song, strongly believing that they could overcome the disease.

Dance can be regarded as the most direct way for human beings to express themselves. Beibei, a 5-year-old girl who had been in the isolation ward of the Children's Medical Center of Taihe Hospital in Shiyan City, Hubei Province, was discharge on February 17, 2020, after 16 days of treatment and care by the pediatricians and nurses. At this time of celebration, the medical staff taking care of the little girl gave her a little teddy bear and other presents. It was time to leave the hospital. She was too young to express herself in words to those who had established a deep connection with her having taken care of her for more than half a month. Instead, she improvised a dance to show her gratitude when it was time to leave. Despite the form of improvisation, she was dancing from her heart so that each medical worker present felt very touched.

\section{Medical workers actively joining in dancing}

Hao Yan, regarded as the "director" for the cabin hospital, was a member of the medical team of Yijishan Hospital of Wannan Medical College from Anhui Province, China. A patient in a purple coat first caught her attention and praise, when the medical staff was inspecting the ward, a woman was doing some basic exercising near her bed with wellcoordinated and smooth movements. After being encouraged by the medical staff, the lady began to dance, and other patients slowly joined in with her. Most patients were prone to feeling anxious when they first come to the cabin hospitals. In this case, dance was effective in the recovery process as it enabled the patients to adjust their mood. It was shown that some of the patients who participated in dancing ended up laughing, which was so precious at this difficult time. 
With healthcare workers participating in dancing, patients could feel more confident of overcoming the coronavirus. Bahargul Toleheng, is a medical worker from the Xinjiang Uygur autonomous region responsible for administrative work, who is good at singing and dancing. Suggested by the team leader, she went into area $\mathrm{C}$ of the temporary hospital in the Wuhan Parlor Exhibition Center and performed two dances in a white protective suit on February 12, 2020 to ease the patients' tension. One was "Joining me in Uygur dances" and the other was a traditional Kazak dance, Kara Jorga, which received wide praise among patients especially for the impressive movements such as flipping wrists and shaking shoulders. On the same day, Haiyan $\mathrm{Wu}$ along with her nursing team from Hainan working at the cabin hospital in the Wuhan International Conference and Exhibition Centre staged a Danzhou Diaosheng performance, a style of local folk music renowned for its beautiful and rhythmic singing, which was listed as a China Intangible Cultural Heritage in 2006. Patients joyfully joined in dancing with the nurses to release their stress. In Area A of the Wuhan Parlor Exhibition Center the medical staff and patients practiced Sichuan "Dam Dance", one kind of Chinese square dance, to the popular song Red Salirang was filmed. This cheerful scene became an Internet sensation at home and abroad after being uploaded, which was played up to 210,000 times according to statistics. Therefore, such a joyful atmosphere was encouraging to both patients and health care workers, which was absolutely fundamental for the patients' recovery.

\section{Dance as an Effective Approach to Combating the Epidemic}

\section{Effects from the kinesiological perspective}

Physical activity is highly beneficial to health from the point view of kinesiology. It can regulate the body systems and organs and increase lung capacity for the respiratory system. As the main symptoms of COVID-19 are coughing and shortness of breath, taking exercise enables the patients with mild symptoms to facilitate air intake and gas exchange by taking deeper and more rhythmic breaths which aid in the quick recovery from the coronavirus disease.

For those in self-isolation, their body functions might decline to some extent due to prolonged screen time using TVs, computers and mobile phones within a limited living space. Dancing to soft or lively music is a good choice for workouts as moderate exercise can help one to stay healthy. For those who were basically self-reliant and were showing no severe syndromes, receiving treatment in the temporary hospitals in Wuhan, participating in moderate-intensity activities served well in building up their immune systems. The scientific research has shown that patients' own immunity is a critical factor to fight off the coronavirus. Apart from lowering anxiety through dancing, it is particularly vital for patients to strengthen their immune system to shorten the recovery process. 


\section{Effects from a psychological point of view}

From a psychological point of view, patients have suffered greatly from the novel coronavirus, both physically and mentally. Fear is a common instinct we all have. It is indeed challenging to stay positive and optimistic especially when facing the spread of the epidemic. We should pay close attention to self-prevention while moderately relieving mental stress through physical activities. Dance can maintain and enhance physical fitness and overall health as well as being instrumental for mental adjustment to shorten the course of disease.

For people living in home isolation, they might be at a loss in the face of this white war of epidemic, however, they have to adjust to facing the current situation. Therefore, dance is highly effective to increase physical fitness and provide mental relief. Meanwhile, the medical staff has made efforts to help patients to adapt to the community at the cabin hospitals through dance and movement in order to stay positive and strengthen their own immune system to defeat the virus. To adjust their mood patients also help each other and cheer for each other through dance. As medical workers join in dancing with the patients, they are creating an increasing warm and relaxed atmosphere, which is beneficial to build up confidence and to defeat the coronavirus.

\section{Conclusion}

Love spreads more rapidly than the virus. Staying positive is of the upmost importance in response to the emerging COVID-19 pandemic. Those staying home and practicing social distancing can calm their anxiety and improve their immune system through dance and movement by staying fit and active. Patients with mild symptoms should get medical treatment and be optimistic in the face of the coronavirus while strengthening their immune system to shorten the course of their recovery from COVID-19.

\section{About the Author}

Zhang Wei, Associate Professor, Dean for Dance and Cultural Research Center in Sichuan University of Media and Communications. He is the Deputy Dean at the Department of Dance. His research direction involves Dance Studies and the Anthropology of Art. E-mail: 6409141@qq.com

\section{References}

Pia, Y.G. (2009). Introduction to dance culture. Beijing: Central University for Nationalities Publishing House.

Yu, P. (1999). The human spiri-dance culture and dance aesthetic. Beijing: China Renmin University Press. Yuan, H. (2011). Dance and traditional culture. Beijing: Peking University Press. 